\section{Determining Optimal Electrical Conductivity Levels and Elements for Extended Vase Life of Cut Roses}

\author{
Erin M.R. Clark ${ }^{1}$, John M. Dole ${ }^{1}$, and Jennifer Kalinowski ${ }^{1}$
}

ADDITIONAL INDEX wORDs. EC, micronutrients, nutrients, $\mathrm{pH}$, postharvest, salt, water quality

Summary. Six experiments were conducted using three cultivars to investigate the impact of water electrical conductivity (EC) and the addition of nutrients to vase solutions on postharvest quality of cut rose (Rosa hybrids) stems. Postharvest quality of cut 'Freedom' rose stems was evaluated using solutions containing either distilled water with sodium chloride $(\mathrm{DW}+\mathrm{NaCl})$ or $\mathrm{DW}+\mathrm{NaCl}$ with the addition of a commercial floral preservative (holding solution containing carbohydrates and biocide) to generate a range of EC values (Expts. 1 and 2). The third experiment compared the effect of different EC levels from the salts $\mathrm{NaCl}$, sodium sulfate $\left(\mathrm{Na}_{2} \mathrm{SO}_{4}\right)$, and calcium chloride $\left(\mathrm{CaCl}_{2}\right)$. The fourth experiment investigated EC's impact on rose stems with the addition of two rose cultivars (Charlotte and Classy). When 'Freedom' stems were subjected to $\mathrm{DW}+\mathrm{NaCl}$, the longest vase life was achieved with $0.5 \mathrm{dS} \cdot \mathrm{m}^{-1}$. The addition of holding solution not only extended vase life but also counteracted the negative effects of high EC with maximum vase life occurring at $1.0 \mathrm{dS} \cdot \mathrm{m}^{-1}$. Furthermore, stems in the holding solution experienced significantly less bent neck and the flowers opened more fully than those in DW. Stems placed in DW with a holding solution also experienced more petal bluing, pigment loss, necrotic edges, and wilting than those held in DW alone. This effect was likely due to increased vase life. Salt solutions containing $\mathrm{Na}_{2} \mathrm{SO}_{4}$ and $\mathrm{CaCl}_{2}$ resulted in extended vase life at $1.0 \mathrm{dS} \cdot \mathrm{m}^{-1}$, but increasing salt levels decreased overall vase life. As EC increased, regardless of salt type, water uptake also increased up to a maximum at 0.5 or $1.0 \mathrm{dS} \cdot \mathrm{m}^{-1}$ and then continually declined. Maximum vase life was observed at 1.5 $\mathrm{dS} \cdot \mathrm{m}^{-1}$ for cut 'Charlotte' stems, and at $1.0 \mathrm{dS} \cdot \mathrm{m}^{-1}$ for 'Classy' with the addition of a holding solution. Physiological effects were different based on cultivar, as observed with Charlotte and Freedom flowers that opened further and had less petal browning than Classy flowers. 'Freedom' had the greatest pigment loss, but this effect decreased with increasing EC. Further correlational analysis showed that in water-only solutions, initial and final EC accounted for $44 \%$ and $41 \%$ of the variation in vase life data, respectively, whereas initial $\mathrm{pH}$ accounted for $24 \%$ of variation. However, the presence of carbohydrates and biocides from the holding solution was found to have a greater effect on overall vase life compared with water $\mathrm{pH}$ or EC. Finally, in Expts. 5 and 6, cut 'Freedom' stems were subjected to DW solutions containing $0.1,1,10$, or $100 \mathrm{mg} \cdot \mathrm{L}^{-1}$ boron, copper, iron, potassium, magnesium, manganese, or zinc. None of these solutions increased vase life. Conversely, 10 or $100 \mathrm{mg} \cdot \mathrm{L}^{-1}$ boron and $100 \mathrm{mg} \cdot \mathrm{L}^{-1}$ copper solutions reduced vase life. Finally, the addition of $\mathrm{NaCl}$ to a maximum of 0.83 $\mathrm{dS} \cdot \mathrm{m}^{-1}$ increased the vase life in all solutions. These analyses highlight the importance of water quality and its elemental constituents on the vase life of cut rose stems and that the use of a holding solution can overcome the negative effects of high EC water. vase life. Water $\mathrm{pH}, \mathrm{EC}$, and nutrient content are the three most important water quality factors to consider in postharvest quality (Conrado et al., 1980; Durkin, 1979).

It is well known that vase solution can influence the populations of yeast, bacteria, and fungi, leading to vascular blockage, thus preventing water uptake, and decreasing the longevity of cut roses (Rosa hybrids). Pompodakis et al. (2004) illustrated that a low solution $\mathrm{pH}$ of 6 enhances cut rose water relations, fresh weight maintenance, and vase life. It has also been observed that water held at a $\mathrm{pH}$ higher than 4 may contain a few microbes, but yeasts were found to be absent at the cut surface or inside the xylem of cut rose stems (van Doorn, 1997). Alternatively, too high of a water $\mathrm{pH}$ will likely shorten vase life and reduce water uptake because microbial growth is stimulated. There is a large consensus within the literature that upholding a low $\mathrm{pH}$ solution lowers the chance of microbe contamination and reduces vascular blockage, thereby allowing proper water absorption to increase vase life while deterring microbial growth most harmful to cut flowers (Gast, 2000; Reid and Kofranek, 1980; van Doorn, 1997).

Due to the variability of water quality across the country, growers, wholesalers, and retailers who use tap water for cut flower vase solutions need to strongly consider the quality of water used in storage solutions (Dole, 2012). Sensitivity to water EC varies by species. Carnation (Dianthus caryophullus) and chrysanthemum (Chrysanthemum $\times$ grandiflorum) are reported to prefer a higher water EC level whereas the optimum level is lower for zinnia (Zinnia violacea) (Carlson and Dole, 2013). The U.S. Environmental Protection Agency (EPA) has offered limited and voluntary guidelines
$\mathrm{V}$ ase life of cut flowers is dependent on many variables, including the quality of the water in which the flowers are placed (Conrado et al., 1980; Durkin, 1979; Halevy and Mayak, 1979). Durkin (1979) highlighted the importance of water quality in the vase solution for cut flower longevity, and Conrado et al. (1980) described water quality as the limiting factor for cut flower

\begin{tabular}{llll}
\hline $\begin{array}{l}\text { Units } \\
\begin{array}{l}\text { To convert U.S. to SI, } \\
\text { multiply by }\end{array}\end{array}$ & U.S. unit & SI unit & $\begin{array}{l}\text { To convert SI to U.S., } \\
\text { multiply by }\end{array}$ \\
\hline 29.5735 & $\mathrm{fl} \mathrm{oz}$ & $\mathrm{mL}$ & 0.0338 \\
7.8125 & $\mathrm{fl} \mathrm{oz} / \mathrm{gal}$ & $\mathrm{mL} \cdot \mathrm{L}^{-1}$ & 0.1280 \\
2.54 & inch $(\mathrm{es})$ & $\mathrm{cm}$ & 0.3937 \\
1 & $\mathrm{mmho} / \mathrm{cm}$ & $\mathrm{dS} \cdot \mathrm{m}^{-1}$ & 1 \\
28.3495 & $\mathrm{oz}$ & $\mathrm{g}$ & 0.0353 \\
7.4892 & $\mathrm{Oz} / \mathrm{gal}$ & $\mathrm{g} \cdot \mathrm{L}^{-1}$ & 0.1335 \\
0.001 & $\mathrm{ppm}$ & $\mathrm{g} \cdot \mathrm{L}^{-1}$ & 1000 \\
1 & $\mathrm{ppm}$ & $\mathrm{mg} \cdot \mathrm{L}^{-1}$ & 1 \\
0.001 & $\mathrm{ppm}$ & $\mathrm{mL} \cdot \mathrm{L}^{-1}$ & 1000 \\
$\left({ }^{\circ} \mathrm{F}-32\right) \div 1.8$ & ${ }^{\circ} \mathrm{F}$ & ${ }^{\circ} \mathrm{C}$ & $\left({ }^{\circ} \mathrm{C} \times 1.8\right)+32$
\end{tabular}

Horllechnology $\cdot$ October $202131(5)$ 
for water EC, which specifies a maximum of $500 \mathrm{mg} \cdot \mathrm{L}^{-1}\left(0.7 \mathrm{l} \mathrm{dS} \cdot \mathrm{m}^{-1}\right)$ total dissolved solids (EPA, 201la). However, water EC can fluctuate greatly across the country from facilities, such as College Station, TX $(0.75$ $\left.\mathrm{d} S \cdot \mathrm{m}^{-1}\right)$, San Diego, CA $\left(0.82 \mathrm{dS} \cdot \mathrm{m}^{-1}\right)$, and Madison, WI $\left(<0.93 \mathrm{dS} \cdot \mathrm{m}^{-1}\right)$ (EPA, 201lb). Alternatively, the tap water in Birmingham, AL, has a low EC of only $0.14 \mathrm{dS} \cdot \mathrm{m}^{-1}$ (EPA, 2011b).

The mineral composition of water can also influence vase life of cut flowers. Longevity is reportedly increased with the addition of calcium $(\mathrm{Ca})$, aluminum $(\mathrm{Al})$, boron $(\mathrm{B})$, copper $(\mathrm{Cu})$, nickel $(\mathrm{Ni})$, or zinc $(\mathrm{Zn})$ salts (Nowak and Rudnicki, 1990; van Meeteren et al., 2000). However, Neumaier et al. (1999) found that sodium chloride $(\mathrm{NaCl})$ decreased vase life at concentrations greater than $20 \mathrm{~mm}\left(1.17 \mathrm{~g} \cdot \mathrm{L}^{-1}\right)$ in tap water. The impact of these elements on the EC of vase water solution has not been reported in the literature.

Although work we previously conducted provided information on the effects of $\mathrm{pH}$ (Regan and Dole, 2010 ), the effect of a range of water ECs alone and in combination with specific nutrients has not been tested. Therefore, the objectives of this study were to characterize the effects of water EC and solution elemental composition on rose vase life.

\section{Materials and methods}

Four experiments (Expts. 1-4) were conducted to evaluate the effect of EC on vase life, and two experiments (Expts. 5 and 6) were conducted to evaluate the impact of specific elements on vase life. In each experiment cut 'Freedom' rose stems were received from commercial

Received for publication 28 Feb. 2021. Accepted for publication 11 June 2021

Published online 10 September 2021.

${ }^{1}$ Department of Horticultural Science, North Carolina State University, Box 7609, Raleigh, NC 27695

We gratefully acknowledge industry funding and plant material; support from the floriculture research technicians Ingram McCall and Diane Mays and graduate students Emma Locke, Erin Possiel Moody, and J.B. Clark IV; and editorial comments from Ben Bergmann, Sylvia Blankenship, and William Fonteno.

J.M.D. is the corresponding author. E-mail: john_dole@ncsu.edu.

This is an open access article distributed under the CC BY-NC-ND license (https://creativecommons. org/licenses/by-nc-nd/4.0/).

https://doi.org/10.21273/HORTTECH04833-21 producers (Bogota, Colombia) grown in plastic-covered greenhouse under standard commercial conditions (Mercurio, 2007) and held overnight in a $2{ }^{\circ} \mathrm{C}$ cooler, except for Expt. 4 , where 'Charlotte' and 'Classy' stems were also used. Stems were unpacked and sorted into uniform groups according to stem caliper and flower size, and then recut to a length of 45 $\mathrm{cm}$ in the air. Each replication consisted of three stems in a vase, and each treatment had five replications for a total of 15 stems per treatment. Vases were arranged in a completely randomized design and placed in a postharvest environment at $20 \pm 2{ }^{\circ} \mathrm{C}$ under $\approx 20 \mu \mathrm{mol} \cdot \mathrm{m}^{-2} \cdot \mathrm{s}^{-1}$ light from cool white fluorescent bulbs with a spectrum high in blue and yellow light (Hanan, 1998) for $12 \mathrm{~h} \cdot \mathrm{d}^{-1}$ at $40 \%$ to $60 \%$ relative humidity.

Salts were added to water solutions to create a range of EC levels in each experiment (see Table 1 for formulations). In Expt. 1 sodium chloride $(\mathrm{NaCl})$, which is the primary salt in tap water, was added to distilled water $(\mathrm{NaCl}+\mathrm{DW})$ to create solutions with an EC of $0,0.5,1.0,2.0$, or 4.0 $\mathrm{dS} \cdot \mathrm{m}^{-1}$ or to DW with a floral preservative containing carbohydrates and biocide [hereafter referred to as holding solution (HS; $\mathrm{NaCl}+\mathrm{DW}+\mathrm{HS}$; $10 \mathrm{~mL} \cdot \mathrm{L}^{-1}$ Floralife Professional 2; Floralife, Walterboro, $\mathrm{SC}]$ to produce solutions with an EC of 0.4, 0.5, 1.0, 2.0 , or $4.0 \mathrm{dS} \cdot \mathrm{m}^{-1}$. Expt. 2 was a repeat of Expt. 1 with more EC values evaluated. $\mathrm{NaCl}$ was added to $\mathrm{DW}$ to produce solutions with an EC of 0 , $0.25,0.5,0.75,1.0,2.0,2.5,3.0$, 3.5 , or $4.0 \mathrm{dS} \cdot \mathrm{m}^{-1}$ or to DW plus HS $\left(10 \mathrm{~mL} \cdot \mathrm{L}^{-1}\right)$ to produce solutions with an EC of $0.4,0.5,1.0,2.0$, or $4.0 \mathrm{dS} \cdot \mathrm{m}^{-1}$. Solution $\mathrm{pH}$ was then measured (Table 1). Tap water $(\mathrm{pH}$ 6.82, EC $0.27 \mathrm{dS} \cdot \mathrm{m}^{-1}$ ) was included as a control. Element levels in the tap water significant for this research were $7.7 \mathrm{mg} \cdot \mathrm{L}^{-1} \mathrm{Ca}, 16.0 \mathrm{mg} \cdot \mathrm{L}^{-1}$ chloride $(\mathrm{Cl}), 41.8 \mathrm{mg} \cdot \mathrm{L}^{-1}$ sodium $(\mathrm{Na})$, and $22.8 \mathrm{mg} \cdot \mathrm{L}^{-1}$ sulfur (S). In Expt. 3, $\mathrm{NaCl}$, sodium sulfate $\left(\mathrm{Na}_{2} \mathrm{SO}_{4}\right)$, and calcium chloride $\left(\mathrm{CaCl}_{2}\right)$ were added to DW to create solutions with an EC of $0.5,1.0,2.0$, or $4.0 \mathrm{dS} \cdot \mathrm{m}^{-1}$. Control solutions of DW and tap water were included. In Expt. 4, vase life of 'Freedom', 'Charlotte', and 'Classy' cut rose stems were trialed in 10 $\mathrm{mL} \cdot \mathrm{L}^{-1}$ holding solutions wherein
$\mathrm{NaCl}$ was added to DW with an EC of $0.4,1.0,1.5,2.75$, or $4.75 \mathrm{dS} \cdot \mathrm{m}^{-1}$. Solution $\mathrm{pH}$ was measured (Table 1 ).

In Expt. 5, sodium borate $\left(\mathrm{Na}_{2} \mathrm{~B}_{4} \mathrm{O}_{7}\right)$, copper sulfate $\left(\mathrm{CuSO}_{4}\right)$, manganese sulfate $\left(\mathrm{MnSO}_{4}\right)$, or zinc sulfate $\left(\mathrm{ZnSO}_{4}\right)$ were added to either $\mathrm{DW}$ or $\mathrm{DW}+\mathrm{NaCl}\left(\mathrm{EC} 0.83 \mathrm{dS} \cdot \mathrm{m}^{-1}\right.$ from $438.8 \mathrm{mg} \cdot \mathrm{L}^{-1} \mathrm{NaCl}$ ) to create final $\mathrm{B}, \mathrm{Cu}$, manganese $(\mathrm{Mn})$, and $\mathrm{Zn}$ concentrations of $0.1,1,10$, and 100 $\mathrm{mg} \cdot \mathrm{L}^{-1}$ (Table 2). Control solutions of DW ( $\mathrm{pH} 4.5$, EC $\left.0.00 \mathrm{dS} \cdot \mathrm{m}^{-1}\right)$ and $\mathrm{DW}+\mathrm{NaCl}(\mathrm{pH} 5.0$, EC 0.83 $\mathrm{dS} \cdot \mathrm{m}^{-1}$ ) were included. In Expt. 6, iron sulfate $\left(\mathrm{FeSO}_{4}\right)$, potassium sulfate $\left(\mathrm{KSO}_{4}\right)$, and magnesium sulfate $\left(\mathrm{MgSO}_{4}\right)$ were added to either DW or $\mathrm{DW}+\mathrm{NaCl}$ (EC $0.84 \mathrm{dS} \cdot \mathrm{m}^{-1}$ from $\left.438.8 \mathrm{mg} \cdot \mathrm{L}^{-1} \mathrm{NaCl}\right)$ to create final iron $(\mathrm{Fe})$, potassium $(\mathrm{K})$, and magnesium $(\mathrm{Mg})$ concentrations of $0.1,1$, 10 , and $100 \mathrm{mg} \cdot \mathrm{L}^{-1}$ (Table 2). Control solutions of DW $(\mathrm{pH} 4.0, \mathrm{EC}$ $\left.0.00 \mathrm{dS} \cdot \mathrm{m}^{-1}\right)$ and $\mathrm{DW}+\mathrm{NaCl}(\mathrm{pH}$ 4.8 , EC $0.84 \mathrm{dS} \cdot \mathrm{m}^{-1}$ ) were included. Solution initial $\mathrm{pH}$ and EC values were recorded (Table 2 ).

Data collected included vase life in days, initial and termination fresh and dry weight for one stem per vase, water uptake, stage of opening, cause for termination, and final solution $\mathrm{pH}$ and EC. Stage of openness was recorded as 1 for tight (petals upright, some outer petals may be slightly reflexed); 2 for medium (all whorls beginning to reflex); 3 for open (outer whorls completely reflexed, all whorls reflexing to a high degree); and 4 for fully open (stamens visible). Causes for termination were documented as either present or not present on each stem and included bent neck, and petal bluing, browning (entire petal is necrotic), pigment loss (whitening of petal tissue), necrotic edges, and wilting. Except for browning, the first appearance of any of the conditions was scored as being present. Data were analyzed using analysis of variance, means were separated using Tukey's multiple-comparison procedure at $P \leq 0.05$, and correlations were assessed using PROC CORR in SAS (version 9.1; SAS Institute, Cary, NC). Where appropriate, relationships between parameters were fitted to non-linear regression models using spreadsheet software (Excel; Microsoft Corp., Redmond, WA). 


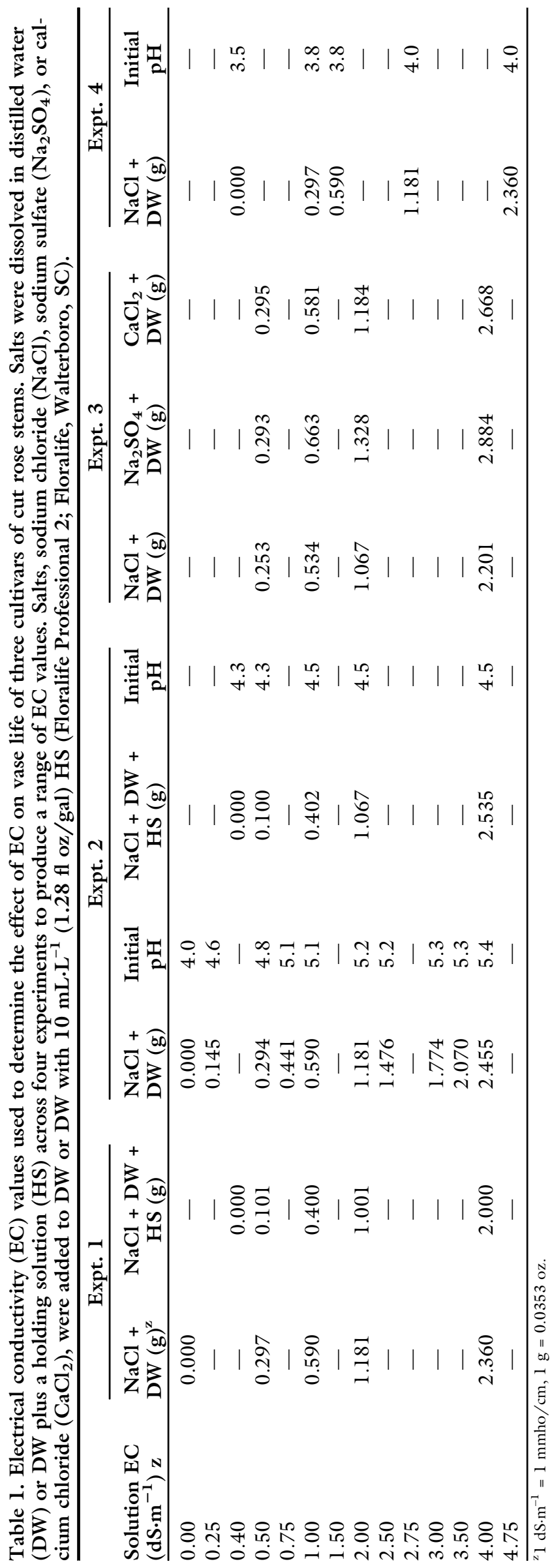

\section{Results}

EC RANGE. Results from Expts. 1 and 2 were similar; thus, only Expt. 2 data from the expanded range of values are presented here. Vase life decreased with increasing EC in both DW+ $\mathrm{NaCl}$ and $\mathrm{DW}+\mathrm{NaCl}+\mathrm{HS}$ (Fig. $\mathrm{lA}$ ). Correlational analysis showed that in $\mathrm{DW}+\mathrm{NaCl}$ solutions, initial and final EC accounted for $44 \%$ and $41 \%$ of variation in vase life data, respectively, and initial $\mathrm{pH}$ accounted for $24 \%$ of variation (Table 3). Correlations were not significant for final $\mathrm{pH}$ of $\mathrm{DW}+\mathrm{NaCl}$ solutions or solutions with holding solution. When data from solutions with and without holding solution were combined, more of the variation was due to $\mathrm{pH}(52 \%$ to $61 \%)$ than due to EC $(20 \%$ to $24 \%)$. Overall, stems in holding solutions had a significantly longer vase life (14.6 to $15.7 \mathrm{~d}$ ) than those without a holding solution (7.8 to $12.9 \mathrm{~d}$ ).

The occurrence of bent neck increased with increasing EC values for $\mathrm{DW}+\mathrm{NaCl}$, but use of the holding solution decreased bent neck to nearly 0\% (Fig. 1B). Conversely, flower opening (Fig. 1C) and pigment loss (Fig. ID) were greatest in holding solutions. Petal bluing decreased to $20 \%$ in $\mathrm{DW}+\mathrm{NaCl}$ at $3.5 \mathrm{dS} \cdot \mathrm{m}^{-1}$ but was consistently $100 \%$ with a holding solution at all EC levels (Fig. 1E). Petal wilt occurrence for stems maintained in $\mathrm{DW}+\mathrm{NaCl}$ and $\mathrm{DW}+\mathrm{NaCl}+\mathrm{HS}$ reached $100 \%$ in both solutions with increasing EC (Fig. IF). Overall, petal necrotic edges decreased with increasing $\mathrm{EC}$ in $\mathrm{DW}+\mathrm{NaCl}$ (Fig. IG).

Water uptake was similar for both treatments and decreased with increasing EC (Fig. 1H). Neither holding solution nor EC had a significant effect on initial fresh weight, termination fresh weight, or weight change; averages were $29.4,23.5$, or $5.9 \mathrm{~g} / \mathrm{stem}$, respectively (data not presented). Termination dry weight increased linearly with increasing EC, reaching $7.0 \mathrm{~g}$ at $4.0 \mathrm{dS} \cdot \mathrm{m}^{-1}$ (data not presented). Final $\mathrm{pH}$ elevated with increasing solution $\mathrm{EC}$ for $\mathrm{DW}+\mathrm{NaCl}$ solutions (Fig. II). Final solution EC values were greater than the initial EC values (Fig. 1J). The difference was greater as the initial EC increased and for solutions containing a holding solution.

SAlt TYPE. Overall, a decrease occurred in vase life for all three salt solutions as solution EC values 
Table 2. Electrical conductivity (EC) values of mineral element treatments used to determine the effect of elements on vase life of 'Freedom' cut rose stems. Elemental salts were dissolved in distilled water (DW) or DW and sodium chloride (NaCl) across two experiments to produce a range of $\mathrm{pH}$ and $\mathrm{EC}$ values. The $\mathrm{pH}$ and $\mathrm{EC}$ values of solutions were formulated by adding sodium borate $\left(\mathrm{Na}_{2} \mathrm{~B}_{4} \mathrm{O}_{7}\right)$, copper sulfate $\left(\mathrm{CuSO}_{4}\right)$, manganese sulfate $\left(\mathrm{MnSO}_{4}\right)$, or zinc sulfate $\left(\mathrm{ZnSO} \mathrm{Z}_{4}\right)$ in Expt. 5 and iron sulfate $\left(\mathrm{FeSO}_{4}\right)$, potassium sulfate $\left(\mathrm{KSO}_{4}\right)$, and magnesium sulfate $\left(\mathrm{MgSO}_{4}\right)$ in Expt. 6 to DW or solutions with $438.8 \mathrm{mg} \cdot \mathrm{L}^{-1} \mathrm{NaCl}$.

\begin{tabular}{|c|c|c|c|c|c|c|c|c|}
\hline \multirow[b]{3}{*}{ Concn $\left(\mathrm{mg} \cdot \mathrm{L}^{-1}\right)^{\mathrm{z}}$} & \multicolumn{4}{|c|}{$\mathrm{Na}_{2} \mathrm{~B}_{4} \mathrm{O}_{7}$} & \multicolumn{4}{|c|}{$\mathrm{CuSO}_{4}$} \\
\hline & \multicolumn{2}{|r|}{$+\mathrm{DW}$} & \multicolumn{2}{|r|}{$+\mathrm{NaCl}$} & \multicolumn{2}{|r|}{$+\mathrm{DW}$} & \multicolumn{2}{|r|}{$+\mathrm{NaCl}$} \\
\hline & $\mathrm{pH}$ & $\mathrm{EC}\left(\mathrm{dS} \cdot \mathrm{m}^{-1}\right)^{\mathrm{z}}$ & $\mathrm{pH}$ & $\mathrm{EC}\left(\mathrm{dS} \cdot \mathrm{m}^{-1}\right)$ & $\mathrm{pH}$ & $\mathrm{EC}\left(\mathrm{dS} \cdot \mathrm{m}^{-\mathbf{1}}\right)$ & $\mathrm{pH}$ & $\mathrm{EC}\left(\mathrm{dS} \cdot \mathrm{m}^{-1}\right)$ \\
\hline 0.1 & 4.8 & 0.00 & 5.4 & 0.83 & 4.3 & 0.00 & 5.4 & 0.83 \\
\hline 1 & 5.3 & 0.00 & 6.4 & 0.84 & 4.1 & 0.00 & 5.3 & 0.84 \\
\hline 10 & 7.9 & 0.00 & 8.7 & 0.85 & 4.3 & 0.01 & 5.2 & 0.86 \\
\hline 100 & \multicolumn{2}{|r|}{$+\mathrm{DW}$} & \multicolumn{2}{|r|}{$+\mathrm{NaCl}$} & \multicolumn{2}{|r|}{$+\mathrm{DW}$} & \multicolumn{2}{|r|}{$+\mathrm{NaCl}$} \\
\hline Concn $\left(\mathrm{mg} \cdot \mathrm{L}^{-1}\right)$ & $\mathrm{pH}$ & $\mathrm{EC}\left(\mathrm{dS} \cdot \mathrm{m}^{-1}\right)$ & $\mathrm{pH}$ & $\mathrm{EC}\left(\mathrm{dS} \cdot \mathrm{m}^{-1}\right)$ & $\mathrm{pH}$ & $\mathrm{EC}\left(\mathrm{dS} \cdot \mathrm{m}^{-1}\right)$ & $\mathrm{pH}$ & $\mathrm{EC}\left(\mathrm{dS} \cdot \mathrm{m}^{-1}\right)$ \\
\hline 0.1 & 5.1 & 0.00 & 5.1 & 0.83 & 5.0 & 0.00 & 5.1 & 0.83 \\
\hline 1 & 4.8 & 0.00 & 5.3 & 0.86 & 4.8 & 0.00 & 5.2 & 0.84 \\
\hline Concn $\left(\mathrm{mg} \cdot \mathrm{L}^{-1}\right)$ & $\mathrm{pH}$ & $\mathrm{EC}\left(\mathrm{dS} \cdot \mathrm{m}^{-1}\right)$ & $\mathrm{pH}$ & $\mathrm{EC}\left(\mathrm{dS} \cdot \mathrm{m}^{-1}\right)$ & $\mathrm{pH}$ & $\mathrm{EC}\left(\mathrm{dS} \cdot \mathrm{m}^{-1}\right)$ & $\mathrm{pH}$ & $\mathrm{EC}\left(\mathrm{dS} \cdot \mathrm{m}^{-1}\right)$ \\
\hline 0.1 & 4 & 0.00 & 4.7 & 0.84 & 4.6 & 0.00 & 4.8 & 0.84 \\
\hline 1 & 3.8 & 0.00 & 4.8 & 0.85 & 4.3 & 0.00 & 4.8 & 0.87 \\
\hline 10 & 4 & 0.01 & 4.7 & 0.88 & 4.4 & 0.02 & 4.8 & 0.89 \\
\hline \multirow[t]{3}{*}{100} & 4.1 & 0.19 & 4.3 & 1.06 & 4.8 & 0.26 & 4.9 & 1.11 \\
\hline & \multicolumn{4}{|c|}{$\mathrm{MgSO}_{4}$} & & & & \\
\hline & \multicolumn{2}{|r|}{$+\mathrm{DW}$} & \multicolumn{2}{|r|}{$+\mathrm{NaCl}$} & & & & \\
\hline Concn $\left(\mathrm{mg} \cdot \mathrm{L}^{-1}\right)$ & $\mathrm{pH}$ & $\mathrm{EC}\left(\mathrm{dS} \cdot \mathrm{m}^{-1}\right)$ & $\mathrm{pH}$ & $\mathrm{EC}\left(\mathrm{dS} \cdot \mathrm{m}^{-1}\right)$ & & & & \\
\hline 0.1 & 4.4 & 0.00 & 4.8 & 0.84 & & & & \\
\hline
\end{tabular}

${ }^{\mathrm{z}} \mathrm{l} \mathrm{mg} \cdot \mathrm{L}^{-1}=1 \mathrm{ppm}, \mathrm{l} \mathrm{dS} \cdot \mathrm{m}^{-1}=1 \mathrm{mmho} / \mathrm{cm}$.

increased in Expt. 3 (Fig. 2A). However, the $1.0 \mathrm{dS} \cdot \mathrm{m}^{-1}$ treatment resulted in longer vase life for the three salt solutions (Fig. 2A). For all three salt solutions, increasing EC values initially decreased bent neck, but at $4.0 \mathrm{dS} \cdot \mathrm{m}^{-1}$ bent neck increased to 93\% in $\mathrm{NaCl}$ solution, $53 \%$ in $\mathrm{Na}_{2} \mathrm{SO}_{4}$, solution and $7 \%$ in $\mathrm{CaCl}_{2}$ solution (Fig. 2B). Flower opening varied by solution, opening more with increasing EC for solutions containing $\mathrm{CaCl}_{2}$ but opening less with increasing $\mathrm{EC}$ for solutions containing $\mathrm{Na}_{2}$ $\mathrm{SO}_{4}$ (Fig. 2C). Stems placed in water containing $\mathrm{NaCl}$ had greater flower opening with increasing EC to a maximum of 2.5 (on a $1-4$ scale, with 1 being a tight flower) at an EC of 2.0 $\mathrm{dS} \cdot \mathrm{m}^{-1}$, but flower opening declined to 1.3 at $4.0 \mathrm{dS} \cdot \mathrm{m}^{-1}$ (Fig. 2C). Petal pigment loss was greater with increasing EC (up to 60\%) in a solution of $\mathrm{CaCl}_{2}$ at $4.0 \mathrm{dS} \cdot \mathrm{m}^{-1}$ (Fig. 2D). However, maximum pigment loss in $\mathrm{NaCl}$ and $\mathrm{Na}_{2} \mathrm{SO}_{4}$ solutions was $33 \%$ or $25 \%$ at $2 \mathrm{dS} \cdot \mathrm{m}^{-1}$ respectively, which then decreased to $0 \%$ at $4 \mathrm{dS} \cdot \mathrm{m}^{-1}$. Petal bluing was consistently high for stems placed in solutions containing $\mathrm{CaCl}_{2}$, but generally decreased with increasing EC for stems in solutions containing $\mathrm{NaCl}$ and $\mathrm{Na}_{2} \mathrm{SO}_{4}$ (Fig. 2E). Petal browning, necrotic edges, and wilting did not differ significantly among the various salt types or EC levels and averaged $21 \%$, $71 \%$, and $95 \%$, respectively (data not presented).

Water uptake decreased with increasing $\mathrm{EC}$ to 141,136 , and 123 $\mathrm{mL}$ of solution with $\mathrm{Na}_{2} \mathrm{SO}_{4}, \mathrm{NaCl}$, and $\mathrm{CaCl}_{2}$, respectively, at $4.0 \mathrm{dS} \cdot \mathrm{m}^{-1}$ and was positively correlated with vase life (Fig. 2F). The final $\mathrm{pH}$ had the highest elevations with increasing EC for $\mathrm{Na}_{2} \mathrm{SO}_{4}$, ranging from 5.4 at 0.5 $\mathrm{dS} \cdot \mathrm{m}^{-1}$ to 6.8 at $4.0 \mathrm{dS} \cdot \mathrm{m}^{-1}$ (Fig. $2 \mathrm{G})$. The final EC of all solutions was higher than the initial EC, and the difference was greater with higher initial EC (Fig. 2H). Neither salt composition nor EC had a significant effect on initial or termination fresh and dry weights or weight change (data not presented).

Cultivar. In Expt. 4, vase life generally decreased with increasing EC for 'Charlotte', 'Freedom', and 'Classy' (Fig. 3A). Correlational analysis showed that initial and final EC accounted for $55 \%$ and $52 \%$ of variation in vase life, respectively. Initial 

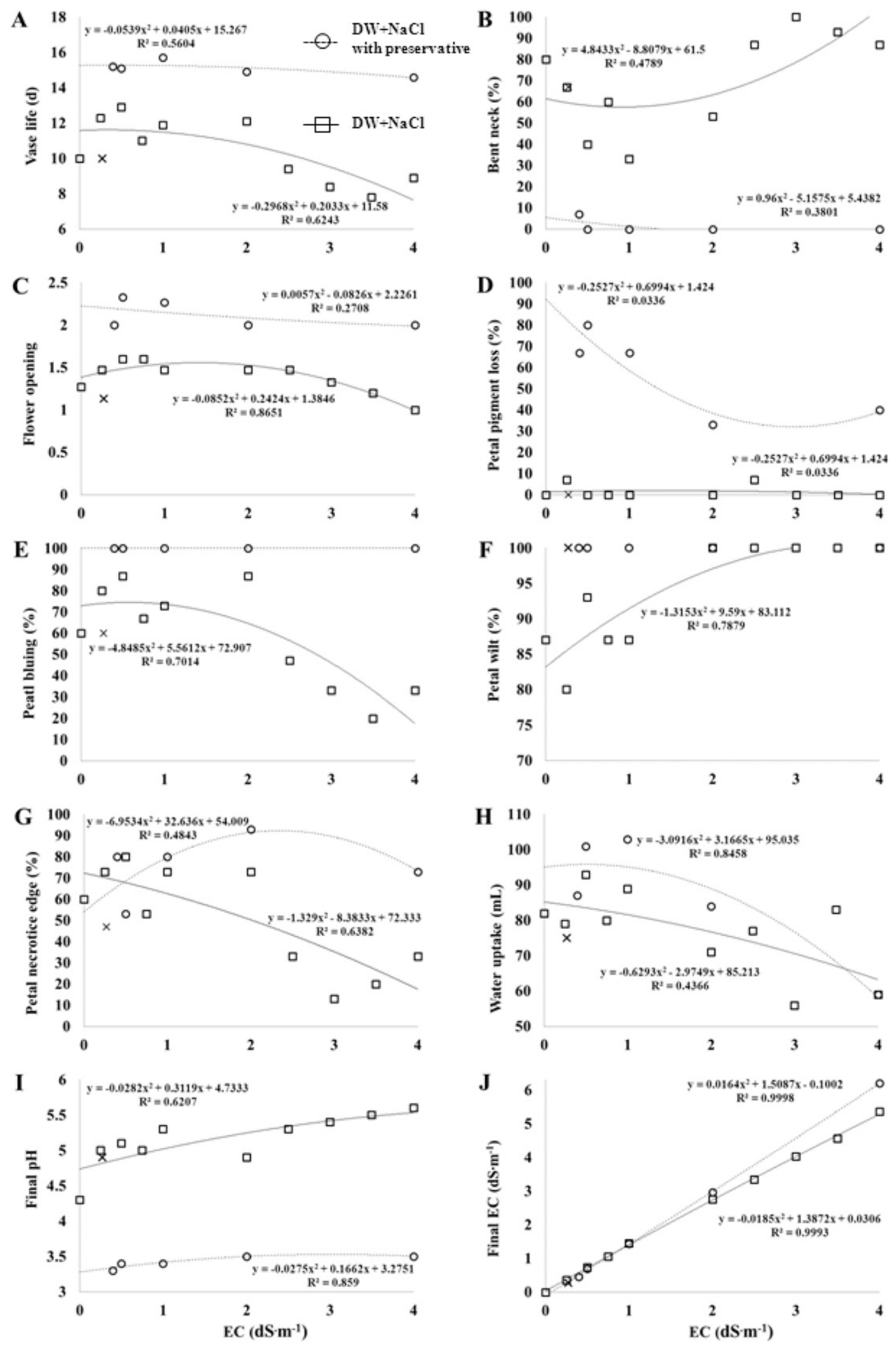

Fig. 1. Expt. 2: vase life and termination criteria of 'Freedom' rose stems were maintained in jars containing either distilled water with sodium chloride $(\mathrm{DW}+\mathrm{NaCl})$ or $\mathrm{DW}+\mathrm{NaCl}$ combined with a holding solution (HS) (Floralife Professional 2; Floralife, Walterboro, SC), at EC levels from 0 to $4.0 \mathrm{dS} \cdot \mathrm{m}^{-1}$. Means represented were average of data from $15 \mathrm{stems}$. A tap water control was included. Data were analyzed for $(\mathrm{A})$ vase life $(P<0.001)$, termination criteria of $(\mathrm{B})$ bent neck $(P<$ $0.001)$, (C) flower opening from stage 1 (tight) to stage 4 (fully open) $(P<0.001)$, (D) petal pigment loss $(P<0.001),(\mathrm{E})$ petal bluing $(P<0.001),(\mathrm{F})$ petal wilt $(P=0.031),(\mathrm{G})$ petal necrotic edges $(P<0.001),(\mathrm{H})$ water uptake $(P=0.002)$, and effect on solution (I) final pH $(P<0.001)$, and (J) final EC $\left(\right.$ EC) $(P<0.001) ; 1 \mathrm{~mL}=0.0338 \mathrm{fl} \mathrm{oz}, 1 \mathrm{dS} \cdot \mathrm{m}^{-1}=1 \mathrm{mmho} / \mathrm{cm}$. 
Table 3. Correlational analysis between vase life of three cultivars of cut rose stems, initial and final EC, and initial and final pH. In Expt. 2, 'Freedom' rose stems were placed in jars containing either distilled water and sodium chloride $(\mathrm{DW}+\mathrm{NaCl})$ or $\mathrm{DW}+\mathrm{NaCl}$ with holding solution (HS) (Floralife Professional 2; Floralife, Walterboro, SC) at EC levels from 0 to $4.0 \mathrm{dS} \cdot \mathrm{m}^{-1}$. In Expt. 4 'Charlotte', 'Classy', or 'Freedom' rose stems were placed in jars containing $\mathrm{DW}+\mathrm{NaCl}$ with HS at EC levels from 0.4 to $4.75 \mathrm{dS} \cdot \mathrm{m}^{-1}$. Data were combined (with and without HS) to determine any correlation of variation based on $\mathrm{HS} ; 1 \mathrm{dS} \cdot \mathrm{m}^{-1}=1 \mathrm{mmho} / \mathrm{cm}$.

\begin{tabular}{|c|c|c|c|c|c|c|c|c|c|}
\hline Cultivar & Solution & \multicolumn{2}{|c|}{ Initial EC } & \multicolumn{2}{|c|}{ Final EC } & \multicolumn{2}{|c|}{ Initial $\mathrm{pH}$} & \multicolumn{2}{|c|}{ Final $\mathrm{pH}$} \\
\hline Freedom & $\mathrm{DW}+\mathrm{NaCl}$ & -0.44 & $* * *$ & -0.41 & $* * *$ & -0.24 & $* *$ & -0.15 & $\mathrm{NS}^{\mathrm{Z}}$ \\
\hline \multirow[t]{2}{*}{ Data combined } & $\pm \mathrm{HS}$ & -0.24 & $* * *$ & -0.20 & $* *$ & -0.52 & $* * *$ & -0.61 & $* * *$ \\
\hline & \multicolumn{9}{|c|}{ Expt. 4} \\
\hline Freedom & $\mathrm{DW}+\mathrm{NaCl}$ with $\mathrm{HS}$ & -0.13 & NS & -0.11 & NS & -0.21 & NS & -0.08 & NS \\
\hline Cultivars combined & $\mathrm{DW}+\mathrm{NaCl}$ with $\mathrm{HS}$ & -0.29 & $* * *$ & -0.25 & $* * *$ & -0.24 & $* * *$ & -0.31 & $* * *$ \\
\hline
\end{tabular}

$*, * * * * *$ Statistically significant differences between sample means based on $F$ test at $P<0.05,0.01$, or 0.001 , respectively. Ns indicates $F$ test for differences between sample means had $P>0.05$.

and final $\mathrm{pH}$ accounted for $30 \%$ and $54 \%$ of variation respectively, on the vase life of 'Classy' stems (Table 3). Correlations were not significant for 'Charlotte' or 'Freedom'. When data from all three cultivars were combined, initial and final EC accounted for $29 \%$ and $25 \%$ of variation in vase life, respectively, and the initial and final $\mathrm{pH}$ accounted for $24 \%$ and $31 \%$ of variation in vase life, respectively.

Bent neck occurred most frequently among cultivars at either low or high EC. However, a determinant was not cultivar, and no significant interactions could be established (Fig. 3B). 'Charlotte' and 'Freedom' flowers opened more than 'Classy' flowers, and flower opening was generally highest with intermediate EC solutions, with no significant interactions between cultivar and EC (Fig. 3C). Freedom had significantly more petal pigment loss than the other cultivars, starting at $80 \%$ at $0 \mathrm{dS} \cdot \mathrm{m}^{-1}$ and decreasing to $20 \%$ with increasing EC. 'Charlotte' and 'Classy' had no pigment loss in low EC solutions and only a slightly higher pigment loss at $4.75 \mathrm{dS} \cdot \mathrm{m}^{-1}$ (Fig. 3D). 'Charlotte' and 'Freedom' had a higher rate of petal bluing at higher EC values than 'Classy' (Fig. 3E). Charlotte experienced significantly less petal browning than the other cultivars, and petal browning was lowest at $1.5 \mathrm{dS} \cdot \mathrm{m}^{-1}$ for all three cultivars with no significant interactions between cultivar and EC (Fig. 3F). 'Charlotte' had the highest rate of petal necrotic edges $(92 \%)$, followed by 'Freedom' and
'Classy' at $88 \%$ and $78 \%$, respectively. Petal necrotic edges were highest at an EC of $1.5 \mathrm{dS} \cdot \mathrm{m}^{-1}$ with no significant interaction between cultivar and EC (data not presented). Petal wilt was unaffected by treatment and averaged $92 \%$ (data not presented).

Water uptake peaked at 156 , 153 , or $172 \mathrm{~mL}$ when stems were placed in $0.4,1.0$, or $1.0 \mathrm{dS} \cdot \mathrm{m}^{-1} \mathrm{EC}$ water for 'Charlotte', 'Classy', or 'Freedom', respectively (Fig. 3G). The final $\mathrm{pH}$ elevated with increasing EC for all three cultivars and was more acidic than the initial $\mathrm{pH}$ (Fig. $3 \mathrm{H})$. The final EC of all solutions for all cultivars was greater than the initial $\mathrm{EC}$ and the difference was greater as the initial EC increased (Fig. 3I).

Initial fresh weight, termination fresh weight, and weight change were unaffected by EC but differed by cultivar $(P \leq 0.05)$; values for Freedom were $26.2,19.2$, and $7.0 \mathrm{~g}$; for Charlotte were $22.7,16.9$, and $5.8 \mathrm{~g}$; and for Classy were $28.9,24.0$, and $4.9 \mathrm{~g}$, respectively. Termination dry weight was unaffected by EC or cultivar and averaged $4.6 \mathrm{~g}$ (data not presented).

Elements. In Expt. 5, vase life was maintained longer $(14.2 \mathrm{~d})$ when stems were placed in a $0.1 \mathrm{mg} \cdot \mathrm{L}^{-1} \mathrm{~B}$ solution with $0.83 \mathrm{dS} \cdot \mathrm{m}^{-1} \mathrm{NaCl}$ (Table 4, some data not presented). All other treatments had either comparable or shorter vase life $(9.1 \mathrm{~d}$ for $10 \mathrm{mg} \cdot \mathrm{L}^{-1} \mathrm{~B}$ in $\mathrm{DW}, 9.0 \mathrm{~d}$ for 100 $\mathrm{mg} \cdot \mathrm{L}^{-1} \mathrm{~B}$ with $\mathrm{NaCl}$, and $9.7 \mathrm{~d}$ for $100 \mathrm{mg} \cdot \mathrm{L}^{-1} \mathrm{Cu}$ in $\mathrm{DW}$ ) than DW, which was $11.8 \mathrm{~d}$ for Expt. 5 and $12.6 \mathrm{~d}$ for Expt. 6 [Table 4 (data for
$\mathrm{Cu}$ not presented)]. Water uptake was positively correlated with vase life $(r=$ $0.20313, P=0.008$ ) and ranged from a low of $106 \mathrm{~mL}$ to a high of $210 \mathrm{~mL}$ (data not presented). Initial fresh weight, termination fresh weight, termination dry weight, and weight change were all unaffected $(P \geq 0.05)$ by treatments in Expts. 5 and 6 .

The initial and final $\mathrm{pH}$ of $\mathrm{B}$ solutions fluctuated with increasing element concentration, regardless of $\mathrm{NaCl}$ presence (Table 4). The $\mathrm{pH}$ started to increase when B levels in the vase solution were low and $\mathrm{pH}$ level decreased with higher $\mathrm{B}$ levels, most notably when $\mathrm{NaCl}$ was added to the solutions. The initial and final $\mathrm{pH}$ of $\mathrm{Cu}, \mathrm{Fe}, \mathrm{K}, \mathrm{Mg}, \mathrm{Mn}$, and $\mathrm{Zn}$ did not differ significantly with element concentration $[P \geq 0.05$ (data not presented)]. However, solutions that contained $\mathrm{NaCl}$ increased $\mathrm{pH}$ of the solution over time (Table 5). Overall, EC was detectably higher than the DW control when 10 or $100 \mathrm{mg} \cdot \mathrm{L}^{-1}$ of each element was added to the vase solution [Table 4 for $\mathrm{B}, P \leq 0.0001$; $\mathrm{Cu}, \mathrm{Fe}, \mathrm{K}, \mathrm{Mg}, \mathrm{Mn}$, or $\mathrm{Zn}$ (data not presented)]. The EC of element solutions or with $\mathrm{NaCl}$ was notably higher than EC of DW solutions.

Stems placed in vase solutions with $0.83 \mathrm{dS} \cdot \mathrm{m}^{-1} \mathrm{NaCl}$ had a lower occurrence of bent neck with a minimum of $20 \%$ in the $\mathrm{NaCl}$ solution and a maximum of $80 \%$ or $87 \%$ without the $\mathrm{NaCl}$ (Tables 4 and 5). Increasing $\mathrm{B}$ concentration in water with $\mathrm{NaCl}$ raised the occurrence of bent neck (Table 4). Alternatively, the presence of 


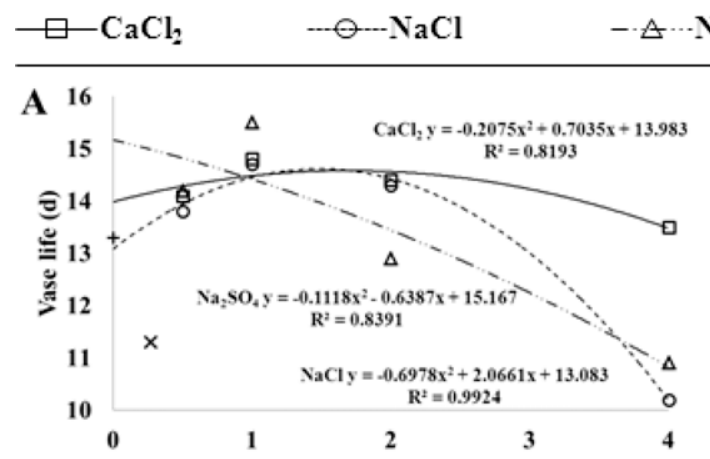

$\mathrm{Na}_{2} \mathrm{SO}_{4}+$ Distilled Water $\quad \times$ Tap Water
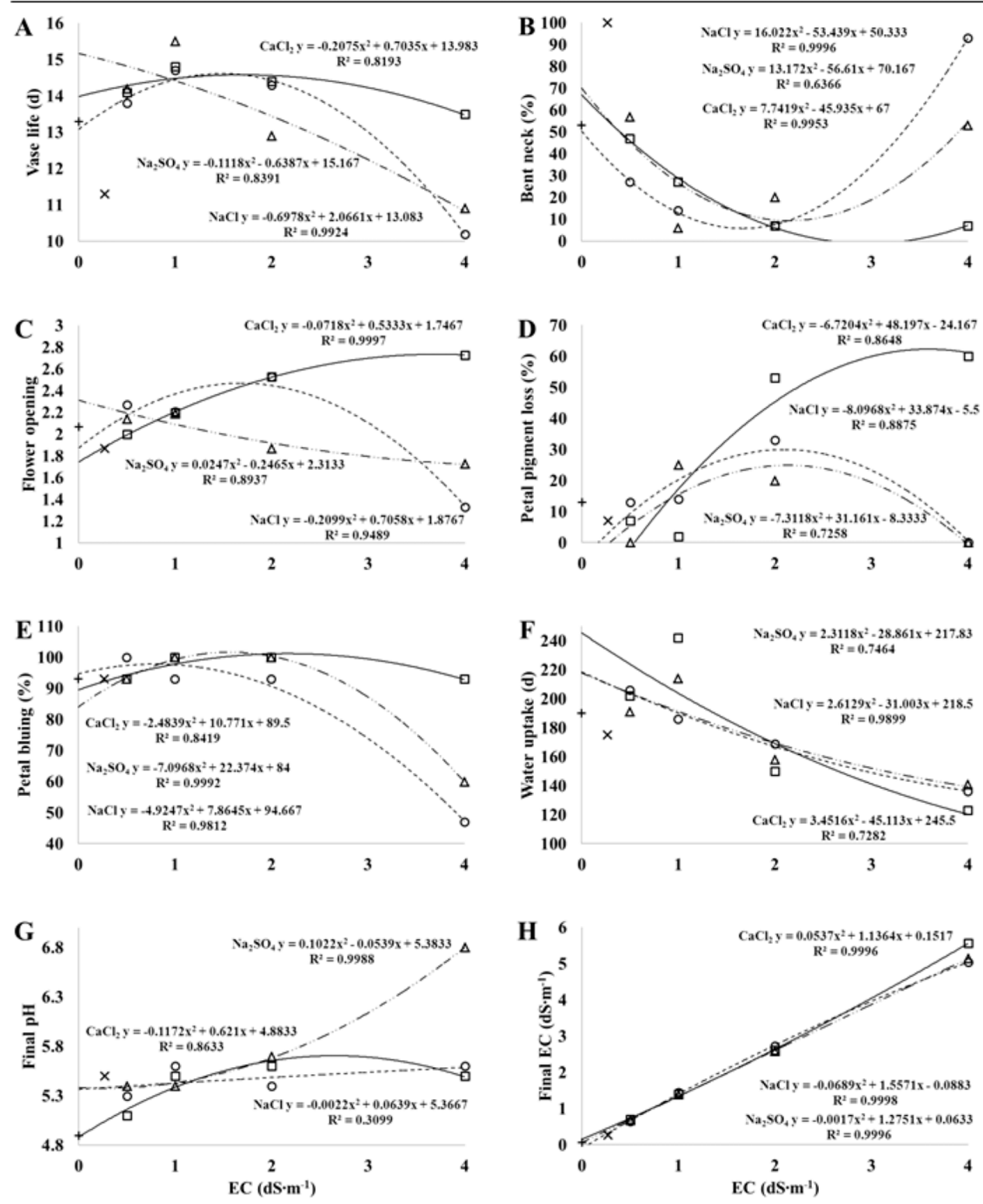

Fig. 2. Expt. 3: Vase life and termination criteria of 'Freedom' rose stems maintained in jars containing varying levels of elemental salts to produce differing EC (EC) levels. Elemental salts used were sodium chloride $(\mathrm{NaCl})$, sodium sulfate $\left(\mathrm{Na}_{2} \mathrm{SO}_{4}\right)$, and calcium chloride $\left(\mathrm{CaCl}_{2}\right)$. EC levels ranged from 0 to $4.0 \mathrm{dS} \cdot \mathrm{m}^{-1}$. Means represented were an average of data from $15 \mathrm{stems}$.

Distilled water and tap water were used as controls. Data were collected on $(\mathrm{A})$ vase life $(P<0.001),(\mathrm{B})$ bent neck $(P<0.001)$,

(C) flower opening stage 1 (tight) to 4 (fully open) $(P<0.001),(\mathrm{D})$ petal pigment loss $(P<0.001),(\mathrm{E})$ petal bluing $(P<0.001)$,

(F) water uptake $(P<0.001),(\mathrm{G})$ final $\mathrm{pH}(P<0.001),(\mathrm{H})$ and final EC $\left.(P<0.001) ; 1 \mathrm{dS} \cdot \mathrm{m}^{-1}=1 \mathrm{mmho} / \mathrm{cm}\right)$.

$\mathrm{Cu}, \mathrm{K}, \mathrm{Mg}, \mathrm{Mn}$, or $\mathrm{Zn}$ in vase solutions with $\mathrm{NaCl}$ lowered the occurrence of bent neck (Table 5). Occurrence of petal bluing was lowest for treatments resulting in shortest vase life $\left(10 \mathrm{mg} \cdot \mathrm{L}^{-1}\right.$ $\mathrm{B}$ in $\mathrm{DW}$ and $100 \mathrm{mg} \cdot \mathrm{L}^{-1}$ in $\mathrm{NaCl}$ water) (Table 4). All stems placed in solution containing $0.1 \mathrm{mg} \cdot \mathrm{L}^{-1} \mathrm{~B}$ with
$\mathrm{NaCl}$ exhibited necrotic edge, while only $33 \%$ of stems placed in solution containing $100 \mathrm{mg} \cdot \mathrm{L}^{-1} \mathrm{~B}$ with $\mathrm{NaCl}$ exhibited necrotic edge at termination. None of the alternative treatments had a significant effect on the occurrence of petal bluing or necrotic edge as compared with the DW control (data not presented). Elemental treatment did not alter stage of opening, petal browning, pigment loss, or wilting to any significant degree (data not presented).

\section{Discussion}

VASE LIFE AND VISUAL QUALITY. An initial EC of 0.5 to $1.0 \mathrm{dS} \cdot \mathrm{m}^{-1}$ 

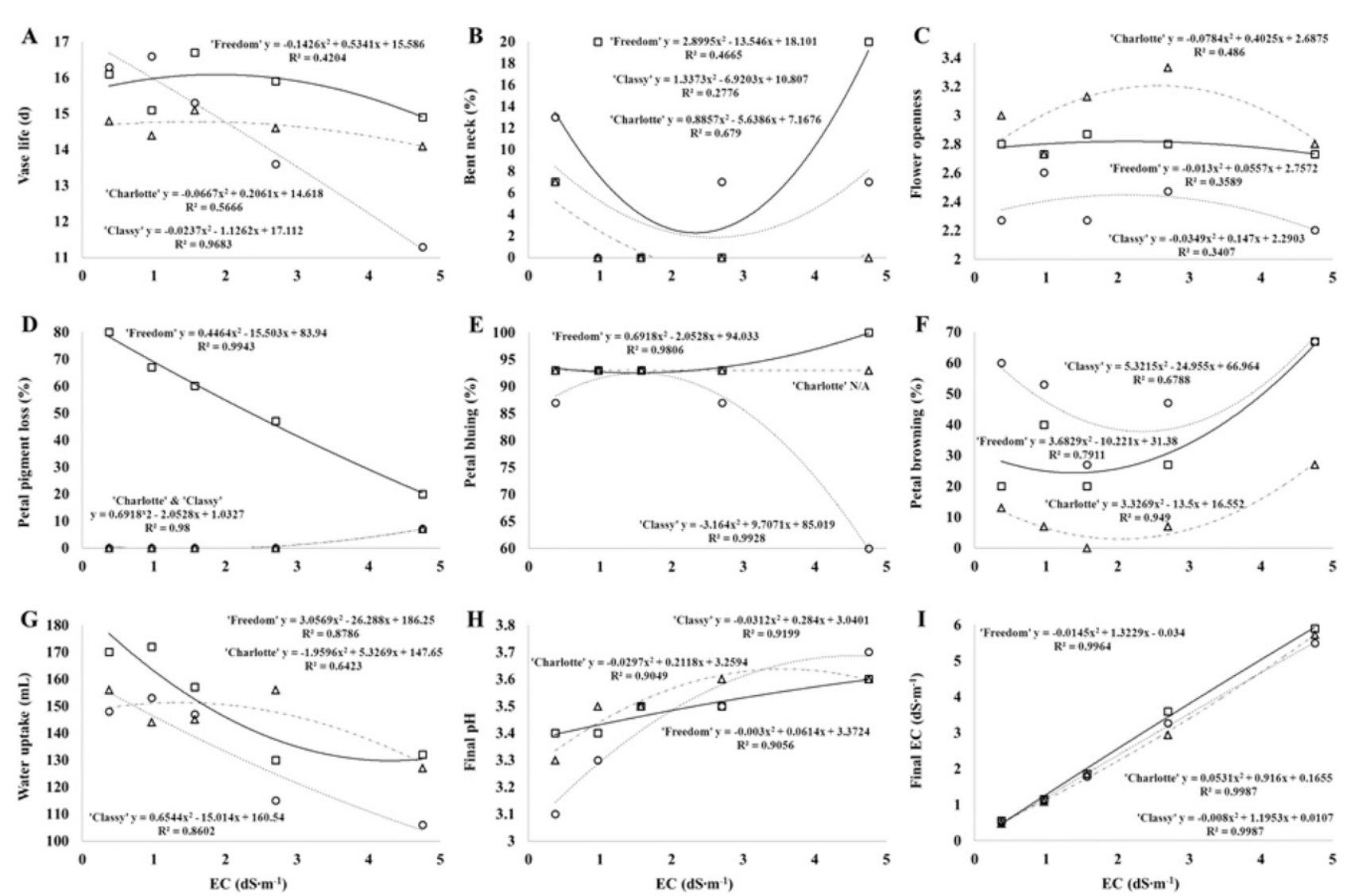

Fig. 3. Expt. 4: Vase life, termination criteria, and solution effects of 'Charlotte', 'Classy', or 'Freedom' rose stems with a range of EC. Stems were maintained in jars containing distilled water with sodium chloride $(\mathrm{DW}+\mathrm{NaCl})$ and holding solution (HS) (Floralife Professional 2; Floralife, Walterboro, SC). The value of EC levels generated ranged from 0.37 to $4.75 \mathrm{dS} \cdot \mathrm{m}^{-1}$. Means represented were an average of data from 15 stems within each cultivar. Data were collected on (A) vase life $(P<0.001),(B)$ bent neck $(P<0.001),(C)$ flower opening stage 1 (tight) to 4 (fully open) $(P<0.001),(\mathrm{D})$ petal pigment loss $(P<0.001),(\mathrm{E})$ petal bluing $(P=0.001),(\mathrm{F})$ petal browning $(P<0.001),(\mathrm{G})$ water uptake $(P<0.001),(\mathrm{H})$ final $\mathrm{pH}(P<0.001)$, and (I) final EC $(P<0.001) ; 1 \mathrm{~mL}=0.0338 \mathrm{fl} \mathrm{oz}, 1 \mathrm{dS} \cdot \mathrm{m}^{-1}=1 \mathrm{mmho} / \mathrm{cm}$.

resulted in the longest vase life in all experiments, regardless of starting solution, salt addition, or cultivar. All flowers placed in $1.0 \mathrm{dS} \cdot \mathrm{m}^{-1}$ vase solutions opened adequately, but two treatments opened more than "medium," which was a rating of 2 (Figs. 1C, 2C, and 3C).

The carbohydrates and biocide in the holding solution were able to overcome the effects of high EC to a degree, extend vase life, and delay bent neck. Carlson and Dole (2013) and Neumaier et al. (1999) also found that floral preservative use negated the deleterious effects of a high EC. Preservatives help to extend vase life by providing the stems with a carbohydrate source, lowering the $\mathrm{pH}$, and preventing bacteria and microbes from causing vascular blockage in stems (Halevy and Mayak, 1979). In Expt. 2 we demonstrated the efficacy of using a holding solution in
$\mathrm{DW}+\mathrm{NaCl}$, while vase life rapidly decreased without the holding solution (Fig. 1A). Furthermore, stems in the holding solution experienced significantly less bent neck and flowers opened more fully than those in just water. This could be due to aluminum sulfate $\left[\mathrm{Al}_{2}\left(\mathrm{SO}_{4}\right)_{3}\right]$ in the holding solution, which may have prevented the occurrence of bent neck (Halevy and Mayak, 1981), whereas the carbohydrates in the holding solution likely encouraged the opening of the flowers similar in other studies (Kuiper et al., 1995; Reid and Kofranek, 1980). Unfortunately, stems placed in water with a holding solution also experienced more petal bluing, browning, necrotic edges, and pigment loss. However, the increase in these disorders was likely due to the extended vase life, allowing the flowers to reach a later stage of senescence.
Reasons for termination varied with the length of vase life. Stems ended earlier typically exhibited bent neck. Stems with a longer vase life had more time to mature, senesce, and exhibit petal bluing, browning, necrotic edges, or pigment loss. Petal wilt occurred regardless of vase life.

Although all cultivars share similar reactions to high EC, there were differences in severity among the cultivars. For example, 'Classy' was more affected by high EC than 'Freedom' or 'Charlotte' in respect to vase life. When EC increased from $1.0 \mathrm{dS} \cdot \mathrm{m}^{-1}$ to $4.75 \mathrm{dS} \cdot \mathrm{m}^{-1}$, 'Classy' vase life decreased 5.3 d whereas 'Freedom' and 'Charlotte' only declined by 0.2 and $0.3 \mathrm{~d}$, respectively. 'Charlotte' and 'Freedom' flowers opened more fully than 'Classy' flowers (Fig. 3C). Conversely, 'Freedom' stems were more prone to pigment loss, whereas 


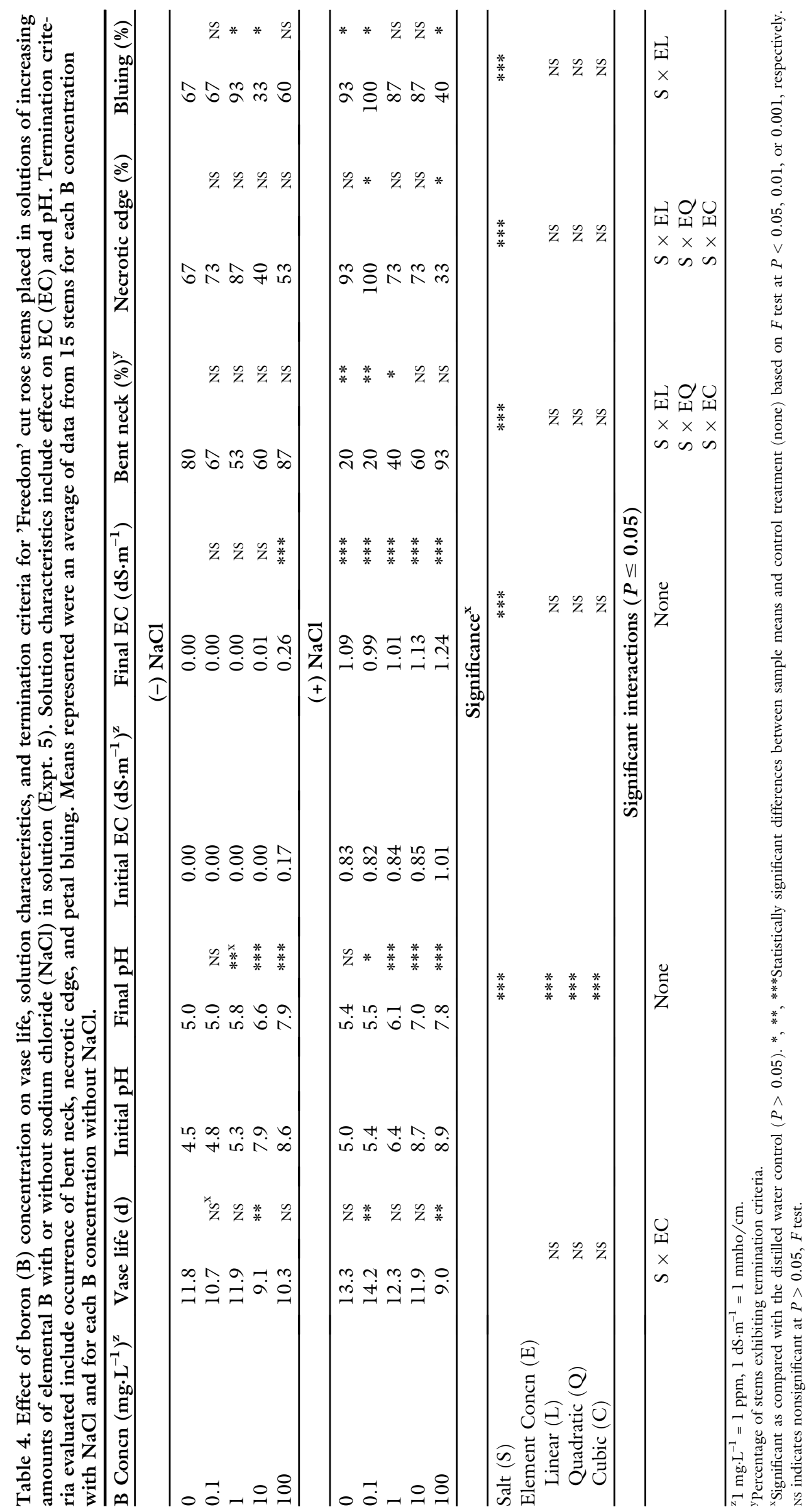


Table 5. Effect of mineral elements on solution characteristics and presence of bent neck in 'Freedom' rose. Solutions contained copper $(\mathrm{Cu})$, manganese $(\mathrm{Mn})$, or zinc $(\mathrm{Zn})($ Expt. 5) and iron $(\mathrm{Fe})$, potassium $(\mathrm{K})$, or magnesium $(\mathrm{Mg})(\mathrm{Expt}$. 6) in distilled water $(\mathrm{DW})$ with or without $0.83 \mathrm{dS} \cdot \mathrm{m}^{-1}$ sodium chloride $(\mathrm{NaCl})$. Means were an average for 60 stems from solutions with $0.1,1,10$, or $100 \mathrm{mg} \cdot \mathrm{L}^{-1}$ of each indicated element and solution type $(\mathrm{DW}$ or $\mathrm{DW}+\mathrm{NaCl}) ; 1 \mathrm{mg} \cdot \mathrm{L}^{-1}=1 \mathrm{ppm}$.

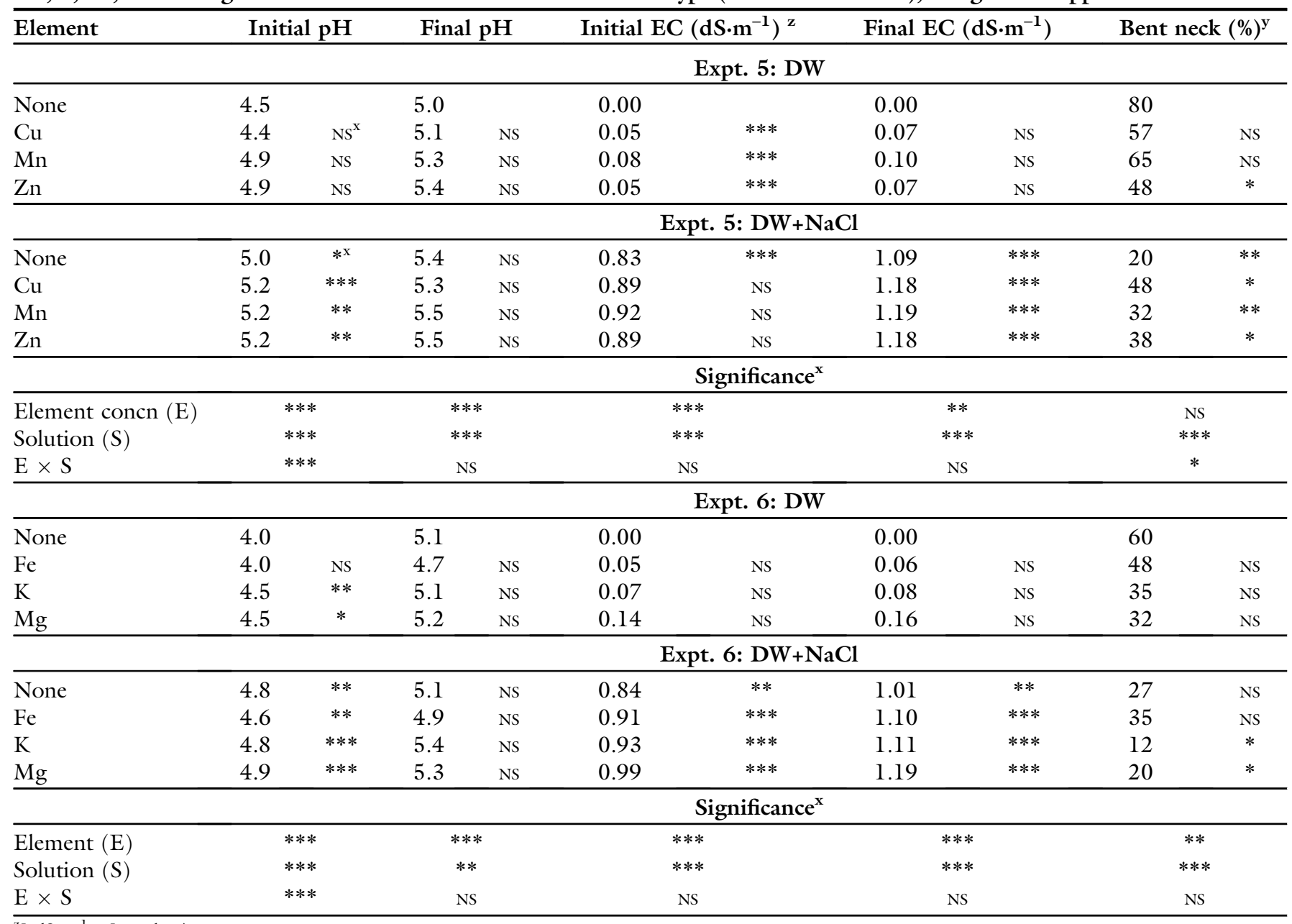

${ }^{\mathrm{z}} 1 \mathrm{dS} \cdot \mathrm{m}^{-1}=1 \mathrm{mmho} / \mathrm{cm}$.

yercentage of stems exhibiting termination criteria.

${ }^{x}$ Significant compared with the distilled water control $(P>0.05) . *, * * * *$ Statistically significant differences between sample means and control treatment (none) based on $F$ test at $P<0.05,0.01$, or 0.001 , respectively. Ns indicates nonsignificant at $P>0.05, F$ test.

stems of 'Charlotte' and 'Classy' experienced up to $7 \%$ pigment loss at 4.75 $\mathrm{dS} \cdot \mathrm{m}^{-1}$, 'Freedom' started at $80 \%$ and decreased to $20 \%$ with less affect by high EC (Fig. 3D).

WATER UPTAKe AND Final EC. Water uptake was correlated to vase life (Expt. 3: $r=0.30859, P=0.009)$, which was correlated to EC (Expt. 3: $r=-0.23872, P=0.001)$. In most cases observations in Expts. 2 and 3 showed that when EC increased, vase life, and water uptake also increased up $1.0 \mathrm{dS} \cdot \mathrm{m}^{-1}$ and thereafter decreased. For example, in Expt. 3, solutions containing $\mathrm{Na}_{2} \mathrm{SO}_{4}$ with $0.5,1.0,2.0$, and $4.0 \mathrm{dS} \cdot \mathrm{m}^{-1}$ resulted in vase life of 14.2 , $15.5,12.9$, and $10.9 \mathrm{~d}$, respectively, and water uptake of 191, 214, 158, and $141 \mathrm{~mL}$, respectively (Fig. 2A and
F). Neumaier et al. (1999) also found a decrease in water uptake as EC increased. van Meeteren et al. (2000) stated that using tap water or a dilute osmoticum improved hydraulic conductance in cut stems over the use of DW. Thus, 0.5 to $1.0 \mathrm{dS} \cdot \mathrm{m}^{-1}$ was an optimal level of an osmoticum in this experiment, and higher levels of soluble salts were damaging.

As stated previously, tap water is quite variable, not only across the country but also from day-to-day in the same location (EPA, 2011b; Halevy and Mayak, 1979). These variances make it difficult to use tap water as a control treatment. In the experiments where tap water $(0.26$ $\mathrm{dS} \cdot \mathrm{m}^{-1}$ ) was used as a control, the results were more like the $0.0 \mathrm{dS} \cdot \mathrm{m}^{-1}$
DW than to a $0.5 \mathrm{dS} \cdot \mathrm{m}^{-1}$ solution of $\mathrm{NaCl}, \mathrm{CaCl}_{2}$, or $\mathrm{Na}_{2} \mathrm{SO}_{4}$ (Figs. $\mathrm{l}$ and $2)$. The studies presented here support an optimal EC of 0.5 to 1.0 $\mathrm{dS} \cdot \mathrm{m}^{-1}$, and most cities surveyed by the EPA possessed tap water within that range (EPA, 2011b). The concentrations of $\mathrm{Ca}, \mathrm{Cl}$, and $\mathrm{Na}$ in the tap water were closer to 0 than to the $0.5 \mathrm{dS} \cdot \mathrm{m}^{-1}$ treatments. Tap water had concentrations of $7.7 \mathrm{mg} \cdot \mathrm{L}^{-1} \mathrm{Ca}$, $16.0 \mathrm{mg} \cdot \mathrm{L}^{-1} \mathrm{Cl}$, and $41.8 \mathrm{mg} \cdot \mathrm{L}^{-1} \mathrm{Na}$; comparatively, the $0.5 \mathrm{dS} \cdot \mathrm{m}^{-1}$ solution had element concentrations of $107 \mathrm{mg} \cdot \mathrm{L}^{-1} \mathrm{Ca}, 181 \mathrm{mg} \cdot \mathrm{L}^{-1} \mathrm{Cl}$, and $117 \mathrm{mg} \cdot \mathrm{L}^{-1} \mathrm{Na}$. The lower concentrations of elements in tap water may explain the similarity in response between the tap water and DW. Interestingly, stems placed in tap water in 
Expt. 3 had a higher occurrence of bent neck $(100 \%)$ when compared with stems maintained in the other treatments, observed to experience a maximum of $57 \%$ bent neck [with the single exception of $93 \%$ bent neck for stems in a $4.0 \mathrm{dS} \cdot \mathrm{m}^{-1} \mathrm{NaCl}$ solution (Fig. 2B)]. This observation may be due to the vase life of stems placed in tap water. Stems with a shorter vase life typically were ended because of bent neck, whereas stems with a longer vase life were generally ended for reasons associated with aging. Tap water consistently had a decreased vase life compared with the other treatments and appeared to be more prone to bent neck. It may first appear that tap water caused bent neck when compared with a holding solution because it can contain aluminum sulfate, which decreased the occurrence of bent neck. However, it is more likely that tap water simply does not prevent the occurrence of bent neck.

The final EC of all solutions was greater than the initial EC, possibly due to solute leakage from degrading tissue. The range became greater as the initial EC increased, and the range increased even more for solutions containing a holding solution. This may have been due to high solution EC levels causing membranes to degrade faster. Final $\mathrm{pH}$ was lower than initial $\mathrm{pH}$ for holding solutions and final $\mathrm{pH}$ was higher for those with water only. In the former situation, organic acid release during tissue degradation may have reduced the vase solution $\mathrm{pH}$. In the latter situation, the likely presence of bacteria in the water-only solutions may have increased $\mathrm{pH}$. Research by Zagory and Reid (1986) demonstrated that the presence of bacteria in vase solutions tended to reduce $\mathrm{pH}$, and the effect was dependent on the type of bacteria present.

In experiments where initial and final $\mathrm{EC}$ and $\mathrm{pH}$ were recorded, correlational analysis showed that in wateronly solutions initial and final EC accounted for $44 \%$ and $41 \%$ of variation in vase life data and initial $\mathrm{pH}$ accounted for $24 \%$ of the variation. In contrast, Regan and Dole (2010) determined that initial EC accounted for $18 \%$ to $48 \%$ of variation in rose vase life (average 36\%), and initial $\mathrm{pH}$ accounted for $30 \%$ to $54 \%$ of variation (average 44\%). However, that study examined a broader $\mathrm{pH}$ range of 3.1 to 8.2 than the current study, which may have accentuated the importance of vase solution $\mathrm{pH}$. In both studies final $\mathrm{pH}$ and $\mathrm{EC}$ were not as strongly correlated with vase life as initial $\mathrm{pH}$ and EC. Interestingly, there were no significant correlations among vase life and vase solution $\mathrm{pH}$ or EC for solutions with a holding solution, except with cultivar Classy in Expt. 4. This indicates that the presence of the carbohydrates and biocide in the holding solution had a greater effect on vase life than water $\mathrm{pH}$ or EC.

EfFects of ELEMENTS. The results from Expts. 5 and 6 suggested that high levels of $\mathrm{Cu}$ and $\mathrm{B}$ reduced vase life, while $\mathrm{Mn}, \mathrm{Zn}, \mathrm{Fe}, \mathrm{K}$, and $\mathrm{Mg}$ did not affect vase life at concentrations of $100 \mathrm{mg} \cdot \mathrm{L}^{-1}$ or less. These results are different from those reported by Neumaier et al. (1999) wherein B, Cu, and $\mathrm{Zn}$ increased vase life of rose. It is well known that mineral elements such as $\mathrm{Cu}$ and $\mathrm{Zn}$ have antimicrobial effects inhibiting the incumbent vascular blockage in the stem xylem cells by bacteria (van Doorn, 1997; van Meeteren et al., 2000). However, different EC levels, nutrient supply, and cultivar could all account for differences in observations. For instance, our data showed that when $\mathrm{Cu}$ reached 100 $\mathrm{mg} \cdot \mathrm{L}^{-1}$, the vase life of stems decreased to $9.7 \mathrm{~d}$, whereas stems placed in lower concentrations did not differ in vase life from stems placed in DW with an average of $11.9 \mathrm{~d}$. There was also no difference in vase life if solutions contained $0.83 \mathrm{dS} \cdot \mathrm{m}^{-1} \mathrm{NaCl}$. Alternatively, a solution of $0.1 \mathrm{mg} \cdot \mathrm{L}^{-1} \mathrm{~B}$ in combination with $\mathrm{NaCl}$ was observed to have a longer vase life than DW, but vase life decreased as B concentration increased. These different effects at higher concentrations could simply be caused by inadequate regulation of water balance, which is the process of regulating water intake to maintain cellular function.

\section{Conclusions}

Overall, our research contributes to how water quality influences postharvest quality of cut roses. The longest vase life resulted when stems were placed in DW with an EC of 0.5 to 1.0 $\mathrm{dS} \cdot \mathrm{m}^{-1}$ or 1.0 to $1.5 \mathrm{dS} \cdot \mathrm{m}^{-1}$ with the addition of holding solution containing carbohydrates and a biocide. Vase life decreased for 'Charlotte', 'Classy', and 'Freedom' as EC increased from these optimum levels. The salts $\mathrm{NaCl}$, $\mathrm{Na}_{2} \mathrm{SO}_{4}$, and $\mathrm{CaCl}_{2}$ provided similar results. Concentrations of $\mathrm{Fe}, \mathrm{K}, \mathrm{Mg}$, $\mathrm{Mn}$, and $\mathrm{Zn}$ at $100 \mathrm{mg} \cdot \mathrm{L}^{-1}$ or lower did not affect the vase life of roses and should not be a concern in postharvest solutions. Only $0.1 \mathrm{mg} \cdot \mathrm{L}^{-1} \mathrm{~B}$ in combination with $0.83 \mathrm{dS} \cdot \mathrm{m}^{-1} \mathrm{NaCl}$ increased vase life. However, 10 $\mathrm{mg} \cdot \mathrm{L}^{-1} \mathrm{~B}$ in DW and $100 \mathrm{mg} \cdot \mathrm{L}^{-1} \mathrm{~B}$ in combination with $0.83 \mathrm{dS} \cdot \mathrm{m}^{-1} \mathrm{NaCl}$ decreased vase life to 9.1 and $9.0 \mathrm{~d}$, respectively. $\mathrm{Cu}$ slightly decreased vase life at a concentration of $100 \mathrm{mg} \cdot \mathrm{L}^{-1}$, which was much higher than the amount of $\mathrm{Cu}\left(1.3 \mathrm{mg} \cdot \mathrm{L}^{-1}\right)$ allowed in drinking water by the EPA (2011b) and thus is unlikely to be a problem with cut flower postharvest.

\section{Literature cited}

Carlson, A.S. and J.M. Dole. 2013. Postharvest water quality affects vase life of cut Dendranthema, Dianthus, Helianthus, and Zinnia. Scientia Hort. 164:277-286, doi: https://doi.org/10.1016/j.scienta.2013. 09.024 .

Conrado, L.L., R. Shanahan, and W. Eisinger. 1980. Effects of $\mathrm{pH}$, osmolarity and oxygen on solution uptake by cut rose flowers. J. Amer. Soc. Hort. Sci. 105:680-683.

Dole, J.M. 2012. Maintaining postproduction quality, p. 463-488. In: P.V. Nelson (ed.). Greenhouse operation and management. 7th ed. Prentice Hall, Upper Saddle River, NJ.

Durkin, D. 1979. Effect of millipore filtration, citric acid, and sucrose on peduncle water potential of cut rose flower. J. Amer. Soc. Hort. Sci. 104:860-863.

Gast, K.L.B. 2000. Water quality: Why it is so important for florists. Kansas State Univ., Agr. Expt. Sta., Coop. Ext. Serv. MF-2436.

Halevy, A.H. and S. Mayak. 1979. Senescence and postharvest physiology of cut flowers. Part 1. Hort. Rev. 1:204-236, doi: https://doi.org/10.1002/97811180607 42.ch5.

Halevy, A.H. and S. Mayak. 1981. Senescence and postharvest physiology of cut flowers. Part 2. Hort. Rev. 3:59-143, doi: https://doi.org/10.1002/978111806076 6.ch3.

Hanan, J.J. 1998. Greenhouses: Advanced technology for protected horticulture. CRC Press, Boca Raton, FL.

Kuiper, D., S. Ribot, H.S. van Reenen, and N. Marissen. 1995. The effect of sucrose on the flower bud opening of 'Madelon' cut roses. Scientia Hort. 60:325-336, doi: 
https://doi.org/10.1016/0304-4238 (94)00706-L.

Mercurio, G. 2007 Cut rose cultivation around the world. Scheurs, De Kwakel, The Netherlands.

Neumaier, D., H.P. Haas, and R. Roeber. 1999. Longevity of cut flowers as influenced by water quality and floral foam. Acta Hort. 482:77-81, doi: https://doi. org/10.17660/ActaHortic.1999.482.10.

Nowak, J. and R.M. Rudnicki. 1990. Postharvest handling and storage of cut flowers, florist greens, and potted plants. Timber Press, Portland, OR.

Pompodakis, N.E., D.C. Joyce, L.A. Terry, and D.E. Lydakis. 2004. Effects of vase solution $\mathrm{pH}$ and abscisic acid on the longevity of cut 'Baccara' roses. J. Hort. Sci. Biotechnol. 79:828-832, doi: https://doi. org/10.1080/14620316.2004.11511850.

Regan, E.M. and J.M. Dole. 2010. Determining optimum $\mathrm{pH}$ and $\mathrm{EC}$ levels for extended vase life of cut Rosa 'Freedom', 'Charlotte', and 'Classy'. Acta Hort. 870: 263-271, doi: https://doi.org/10.17660/ ActaHortic.2010.870.35.

Reid, M.S. and A.M. Kofranek. 1980. Postharvest physiology of cut flowers. Chronica Hort. 20:25-27.

U.S. Environmental Protection Agency. 201la. Drinking water contaminants. U.S. Environ. Protection Agency, Office of Water, Washington, DC.
U.S. Environmental Protection Agency. $2011 \mathrm{~b}$. Water quality assessment and total maximum daily loads information. U.S. Environ. Protection Agency, Office of Water, Washington, DC.

van Doorn, W.G. 1997. Water relations of cut flowers. Hort. Rev. 18:1-85.

van Meeteren, U., H. van Gelder, and W. van Ieperen. 2000. Reconsideration of the use of deionized water as vase water in postharvest experiments on cut flowers. Postharvest Biol. Technol. 18:169-181.

Zagory, D. and M.S. Reid. 1986. Role of vase solution microorganisms in the life of cut flowers. J. Amer. Soc. Hort. Sci. 111:154-158. 